\title{
Mägi on naine, mäendus on mees: etümoloogiline-feministlik vaade Entbergen'ile essees "Küsimus tehnika järele"1
}

\author{
Ave Mets \\ Tartu Ülikooli filosoofia osakonna teadur \\ avemets@ut.ee
}

\begin{abstract}
Teesid: Varjamatus on tõde Heideggeri Kreekast inspireeritud vaates, mis juhtub Entbergen'is - esiletoomises. Tehnoloogia on esile toomise viis. Antiikse ja kaasaegse teadusliku tehnoloogia varjamatused on olemuslikult erinevad: viimase määrab raamistu ehk seadestu, mis on kaasaegse teaduse ja tehnoloogia olemus. Ma pakun etümoloogilis-ökoloogilis-feministliku tõlgenduse antiikse ja kaasaegse tehnoloogia kui ontogeneeside olemustele ning nende pöördepunktile. Tõlgenduse aluseks on Carolyn Merchanti ökofeministlik jutustus ühiskondlikest vaimsetest muutustest, mida põhjustasid tehnilised muutused maaga seotud praktikates (eriti mäenduses) kaubandusrevolutsiooni ja kaasaegse teaduse tekke aegu.
\end{abstract}

Märksõnad: maailmapilt, Martin Heidegger, teaduse ajalugu, teaduslik-tehniline metafüüsika, tehnika ajalugu

\section{Sissejuhatus}

Unverborgenheit (aletheia), mida tõlgitakse varjamatuseks (Matjus 1989; Heidegger 1989), on tõde. See on propositsioonilisele tõele (ehk keeleliste väljendite korrektsusele) eelnev ja selle aluseks olev tõe mõiste, mis viitab kogu olevale, mille kohta väljendid käivad, ning nende tajutavuse võimalikkusele, mis sõltub konkreetsetest ajaloolis-kultuurilistest tingimustest (vt nt Parhomenko 2009: 249, 251; Wrathall 2005). Tehnika on tõe esile toomise, olemise varjamatusse toomise viis, Entbergen'i viis (Heidegger 1959a) ehk tunnetus. Heidegger väidab, et antiikne ja kaasaegne tehnika erinevad olemuslikult neile siseomaste varjamatuste osas, mida nad loovad. See väide on mu artikli peamine ajend. Kuigi kaasaegne tehnika rakendab kaasaegset teadust ning tugineb sellele, jätkub tema olemus teaduses (samas: 29-30). Seega tuleb tehnika praktilist laadi tuginemist teadusele mõista teooria rakendamisest laiemalt - pigem kui kaasaegse tehnika ja teaduse tekke üleüldisi tingimusi. Seega seos teaduse 
kui ontoloogiaga oleks abiks kaasaegse tehnilise varjamatuse olemuse avamiseks võrdluses antiiksega. Ma pakun ajaloolis-etümoloogilis-ökofeministliku tõlgenduse Heideggeri tehnika kui ontogeneesi mõiste aspektile tema essees "Die Frage nach der Technik" (Heidegger 1959a; "Küsimuses tehnika järele", Heidegger 1989). ${ }^{2}$ Vaatlen artiklis mõningaid maailmatunnetuse spirituaalse külje muutusi, mis on tõusnud inimese praktilis-tehnilisest ümberkäimisest loodusega ja mis võiksid olla nüüdisteaduse aluseks. Mu esmane eesmärk on mõista tänapäeva tehnilis-teaduslikku maailmatunnetust, kaasa arvatud tema olemuslikku erinevust teistest maailmamõistmistest, milleks Heideggeri essee (1959a) pakub huvitava filosoofilise lähenemise. Tulenevalt akadeemilisest taustast, on mu lähenemine ennekõike teadusfilosoofiline, mitte haidegeriaanlik, ja lahkneb laiemalt omaksvõetud Heideggeri-tõlgendustest oluliselt. ${ }^{3}$

Ülo Matjus rõhutab järelsõnas Heideggeri nimetatud essee eestindusele (Heidegger 1989), et iga tõlge on tõlgendus, katse tuua enda keelde seda, mis on öeldud teises keeles. Heideggeri puhul on eriti selgesti tajutav, kui raske võib tõlkimine olla: kasutades saksa keele eripärasid, on ta loonud mõistestiku, tervikpildi, millele pole võimalik leida eesti ega inglise keeles sellist vastet, mis säilitaks nii kogu idee kui erinevad pildilised seosed, mis ilmuvad selleni jõudmise teel. Minu tõlgenduses on tuginemine saksa versioonile põhjapaneva tähtsusega, kuna püüan tuua esile mõningaid seoseid, mis senistes tõlgetes esile ei tule. Selleks kõrvutan Carolyn Merchanti jutustust kaasaegse loodusvarade haldamise, tööstuse ja teaduse algusest ökofeministlikus lähenemises (Merchant 1983a) ja Martin Heideggeri algupärast saksa versiooni esseest "Küsimus tehnika järele". Seega kitsendan oma arutelu nimelt Heideggeri käsituse nendele aspektidele, mis sobivad Merchanti jutustusega.

Vaatlusaluses jutustuses Merchant ise Heideggerile ei viita, kuigi ta viitab talle mujal (Merchant 1983b, 2005). Ta toob esile masina mõiste ja mehhanitsistliku maailmapildi ajaloolise korrelatsiooni ning Heideggeri käsituse, mille kohaselt kaasaegse teaduse olemuses on maailma valitsemine mehhanitsistliku printsiibi abil - tema kontrollimine ja tema kalkuleerimine (Merchant 1983b: 228, 234; 2005: 52-53). Sellel tõdemusel on minu tõlgenduses oluline roll; lisaks pakun sellise maailmapildi tekke dünaamikat haaravaid seoseid Heideggeri ja Merchanti tekstide vahel, mida Merchant pole väljendanud.

Artikli esimeses osas seletan lahti mõisted Heideggeri (1959a) saksakeelsest versioonist, mille mõistmine sellisena on aluseks mu tõlgendusele Heideggeri ja Merchanti tekstides esitatud ideede seostest. Seletused on ennekõike etümoloogilised. Kuna etümoloogia tähendab keele kasutamise ajalugu, siis see osutab ka ajaloolistele mõistetele, mis on seotud praktika ja maailmapildiga ning on seetõttu antud arutluses olulised. Teises osas esitan oma tõlgenduse 
materiaalsetest praktikatest (tehnika, mäendus), mis viisid mõtlemise ja maailmapildi muutumiseni lääne kultuuris. Kolmandas osas toon välja kaasaegse teaduse kui selle muutuse tulemuse iseärasused. Kogu artikli läbivaks jooneks on Heideggeri (1959a) käsitlemine Merchanti (1983a) alusel ja vastupidi.

\section{Alusmõisted: maailm, varjamatus, berg}

Tunnetust - maailmatunnetust ja inimese enesetunnetust - kujundab olulisel määral inimese (materiaalne) suhe tema vahetu ümbrusega, sh looduse ja maaga. Seega - mõistmaks üht aspekti Heideggeri eristusest antiikse ja kaasaegse tehnika kui maailma- ja inimesetunnetuste vahel ning seeläbi kaasaegse teaduse maailmapildilisi fundamentaalseid tingimusi, järgin selle suhte arengut mõne materiaalse praktika ajaloolistes momentides, eriti mäenduses kui maaga lähedaselt seotud praktikas, ${ }^{4}$ mis peaaegu ikoonilise kujundlikkusega illustreerib Heideggeri mõistmist tõest kui varjamatusest - Unverborgenheit. ${ }^{5}$ Ka tolle ajastu teadlased võrdlesid omavahel tõele suunatud teaduslikku uurimist ja mäendust: William Gilbert kujutab teaduslikku eksperimenti kui "maa siseosadesse läbitungimist", kusjuures maad näeb ta kui "meie kõigi ema" (Henry 2001: 115; tsiteerides Gilberti De Magnete`t); Robert Boyle sarnastab eksperimentaalset õppimist "kaevanduskäikudes kaevamisega nii kasulike struktuuride jaoks kui seda on loodusfilosoofia kindel tervik" (Agassi 1956 II osa: 99 ja 181, tsiteerides Boyle'i Proemial Essay'd).

Mingis mõttes on 'maailm' - Welt, wer-alds (kes-kõiksus) - ise varjamatusena mõistetav kui miski, mis on tulnud päevavalgusse, saanud teatavaks, avatuks inimtunnetusele ja arusaamisele: see on miski inimese jaoks ja tema läbi, tema (elu)aeg ning koosolemine teiste inimestega, inimestega täidetud ajad ja kohad, mis pakuvad kindlust ja püsimist, turvalisust - vastupidiselt metsikusele või kõrvele (Wildnis), mida tajutakse ohtlikuna (Grimm \& Grimm 1854-1961, viidates sõna 'maailm' (Welt) võimalikule kristlikule päritolule). Kõrb on ohtlik, kuna ta on tundmatu, inimese ja tema mõistmise eest varjatud ning allumatu tema valdamisele. ${ }^{6}$ Olemine ja tõde on üks ja sama (Heidegger 1999: 135-136) - see on tõde kui varjamatus, ehk kuidas olev on, meile ilmneb ja ilmneda saab. Olemine on esile- ehk seisutoodu piiramine (Ergrenzung des zum Stand Gebrachten), mis toimub varjatusest (Verborgenheit) väljumisel, riius, mis kaalub, võrdleb vastaseid (Heidegger 1999: 151; 1966: 87; vt ka Weiner 2001: 92 maa ja ilma vastastikusest määratlemisest). Mäendust võib sel taustal näha kui tegevust, mis avab maa kui tumeda, läbipaistmatu ja varjatu, tuues ta valgusesse ja tehes ta seega (maa)ilma, inimtunnetuse osaks. Inimene avardab 
maailma, oma mõistmist, lükates maailma piire üha edasi kõrve poole - tuues üha enam kõrvest esile valgusse ja varjamatusse seisu, allutades ta oma mõistmisele, ülemvõimule ja valitsemisele. ${ }^{7}$

See tõlgendus on kooskõlas Heideggeri enda mõistmisega maa ja ilma vahekorrast: maa kui mitteinimlik, end meie mõistmise ja võimu eest varjule hoidev, ilm kui inimtegevus ja kavatsused, 'inimese elamise ja asumise' paik (Parhomenko 2009: 251; Weiner 2001: 93). Eduard Parhomenko tekstist leiame veel ühe aspekti Heideggeri 'ilmale': see on 'avatus, millelt inimesed ja asjad saavad oma olemistähenduse, mõtte ja mõõdu'. See tähendab, et maailm pole lihtsalt olevate asjade kogum, vaid mõistmise horisont, millelt neid ühtekuuluvaina ja suhestuvaina ning inimesele suhtutavana mõistetakse (vt ka Heidegger 1965/1929; Wrathall 2005: 349), mis tugevdab eelpool antud etümoloogilist tähendust veelgi.

Mõistmaks paremini tüvega 'berg' ('mägi') seotud sõnu (nt 'bergen', 'verbergen', 'entbergen', 'Gebirge'), vaadakem nende etümoloogiat. 'Berg' ja 'bergen' pärinevad hüpoteetilisest indo-germaani algkeelest ja võivad olla teineteisega seotud, kusjuures Grimmid (1854-1961) väidavad, et 'berg' pärinevat sõnast 'bergen'. 'Bergen' tähendab etümoloogiliselt 'hoidma, alal hoidma, säilitama' (nt vilja, toiduaineid) (Kluge 1989) ja 'kindlasse kohta viima (nt torni), mäkke tooma, päästma' (Grimm \& Grimm 1854-1961; Auberle 2001; Paul 1992); 'berg' tähendab 'kõrge, tasandist kõrguv, kõrgendatud', ka 'ülev, ülistatud'. Mägesid nähti kindla, turvalise kohana, päästena, millest pärineb sama tähendusega 'Burg', ka 'pääste tõele ilmumise eest' (Grimm \& Grimm 1854-1961: 1503, 1505). Viimane pärineb sõjandusest - vägede peitmisest mägede taga (hinter dem berge halten), varjamaks oma sõjalist jõudu vaenlase eest, astumaks talle ootamatult vastu, sundimaks teda seisu (Auberle 2001). Siin võib märgata seoseid, mis ilmuvad nende kahe tähenduse - 'mägi' ja 'hoidma' - vahel. Esiteks, nagu tuleb esile Merchanti selgitustest maa toitva emana mõistmise kohta, hoiab ehk säilitab maa oma vilju (nt metalle ja maake), hoiab neid kindlalt valmimas ja valminuna oma üsas - mägedes, kuna esimesed kaevandustegevused toimusid mägedes (Kluge 1989: 75, märksõna 'Bergbau' - 'mäendus'). Teiseks, säilitamaks vilja ja muid tagavarasid, koguti need kuhjadesse, mis meenutavad kujult mägesid ning mida ka nimetati nii - 'berg' (Grimm \& Grimm 1854-1961), ning varjavad ja hoiavad seda, mis on nende sees ja taga. Ning kolmandaks, tõe hoidmine varjatuses, saladuses, mäe taga, kooskõlastub Heideggeri mõistmisega tõest kui aletheia'st, ning vaenlase vastu astumisest, toomaks teda välja mäe tagant, ja tema mõistmisega olemisest kui riiust kui esile toodavaga vastastikusest piiridesse, esile ja ilmumisse toomisest. ${ }^{8}$ 
Lühidalt, tüve 'berg' tähendustega 'pääste, mägi' ja tuletisega 'Bergbau' (mäendus), on Heideggeril seotud veel järgmised olulised sõnad: bergen - 'päästma' või (otsetõlkes) 'mäkke tooma'; verbergen - 'peitma', 'mäe sees või taga hoidma'; entbergen (see on välja mõeldud) - 'avama', 'varjatusest välja tooma' või 'mäe seest või tagant välja tooma'; Verborgenheit - 'varjatus' või 'mäe sees või taga olu'; Unverborgenheit, aletheia - 'varjamatus' või 'avatud', 'valguses', 'paljandatus'; zutage fördern - 'kaevandama', otsetõlkes 'päevavalgesse tooma'; herausfördern - 'välja sikutama', 'vedama' (tähenduses 'välja kaevandama'); verbauen - 'kaevandust kadudeta ekspluateerima' või 'ehitusega (ka kaevandusega) ära rikkuma'; Gebirg - 'päästetu', 'varjatu kogumus' (päästestu, varjustu), otsetõlkes 'mäeahelik'; Gestell - 'alusraamistik', 'sõrestik', 'kanderaamistik'. Leidub ka teisi väljendeid, mis harmoneeruvad minu järgnevalt esile toodava ökofeministliku käsitlusega.

Söandan rõhutada Heideggeri väljendusi seoses mägedega ja mäendusega kahel põhjusel: esiteks, sõnadel tüvega 'berg', mida eesti keelde tõlgitaks 'mägi', ja mäendusega seotud sõnadel on siin silmapaistvalt oluline roll, ning seda vahel tähendustes, millistes neid tänapäeval ei mõisteta, kuigi neid võidi nõnda mõista mõned sajandid tagasi; tänapäeval on saksa keeles teisi võimalusi nende tähenduste väljendamiseks, mistõttu ma arvan, et tema valik pole "juhuslik". Kuigi Heidegger on varjamatuse mõistet väljendanud mujal ka mitmete teiste sõnadega (Wrathall 2005: 356), siis selle artikli aluseks olevas essees kasutab ta vaid mäe ja maastiku avanemisega seotud sõnu. Teiseks arvan, et see väljendus on eesmärgipärane - Heideggeri viidatav ajalooline side teaduse ja tehnika vahel, nagu mulle näib ja nagu ma näitan Merchanti ökofeministliku käsitluse varal tehnilisest arengust, on mõjutatud inimese suhtest loodusega ehk maaga, selle suhte arengust ja selle peegeldusest vaimses-spirituaalses ja tegevuslikus ilmas. Ka Günter Seubold (1986: 35-36) leiab tehnika olemuse olevat siseomaselt seotud inimese ja maa suhtega: nagu tehnika vahendab inimest ja maad, aidates inimesel teha maad endale kasutatavaks ja teda töödelda, nõnda tekitavad tehnilisemad meetodid inimeses maakaugema meelestuse. Võiks ka öelda: tehnika on inimese ja fysis'e, ${ }^{9}$ looduse, vastastikune piiritlemine, kus nad kehtestavad ja identifitseerivad endid teineteist proovile pannes: inimene loodust tehnilistesse esemetesse ümber korraldades, loodus omalt poolt ette kirjutades, kuidas teda ümber korraldada saab ning inimese ümberkorralduste eesmärkidele allumatuse kaudu.

Kaasaegse tehnika peamine omadus, mis eristab teda antiiksest, öeldakse olevat Gestell $^{10}$ - seadestu või raamistu. See on kaasaegse teaduse olemus ja kaasaegse maailma ontoloogiline struktuur (mitte ontiline, st puudutab mõistmist olevast ja olemisest, mitte olevat ennast) (Seubold 1986: 111), kutsudes 
inimest vaatlema maailma ja loodust kui Bestand' $\mathbf{i}^{11}$ - püsivaru. Seadestu on teaduslik-tehnoloogiline maailmapilt, mis on määratud teaduslike (matemaatiliste) teooriate ja tehnoloogilise mõistmisega maailmast kui manipuleeritavast ja inimese hüvanguks kasutatavast ressursist. Sõnal 'Bestand' on kolm olulist aspekti. Esiteks tähendab ta midagi stabiilset, (püsi)seisu toodut ja seega oma seisus kindlustatut - see viitab korrale, tunnetuslikule läbipaistvusele ja hallatavusele. Teiseks varu või inventuurina on see miski, mida saab väljendada kvantitatiivsetes mõistetes - midagi mõõdetavat ja arvutatavat, ja kolmandaks, sellisena inimese käsutuses ja meelevallas olevat. ${ }^{12}$ Ma tõlgendan raamistut mäenduse raames praktilise ehk tegevusega seotud mehhanismina ekstraheerimise ja kaevandamise käsutuses, mis tuleneb kommerts-kapitalistlikust meelestusest näha maad Bestand'ina ehk püsivaruna, tekitavana ja jätkavana tehno-teaduslikku meelestust näha loodust sellena teoreetilises ja vaimses mõttes. Seega ma püüan tuua esile ühe murdepunkti, mis tõi sisse erinevuse antiikse ja kaasaegse tehnika vahel, millele Heidegger keskendub.

\section{(Tehnilise) tunnetuse suhe mäendusega: ökofilosoofiline analüüs}

Tehnikat (techne) kirjeldab Heidegger kui tõe esiletoomist, tema varjatusest välja toomist - või ka mäe tagant välja ilmumist (Entbergen, aus Verborgenheit her in die Unverborgenheit vor) (Heidegger 1959a: 19). Ühes episteme'ga on ta üks tunnetamise (Erkennen) viis: millegi mõistmine, taipamine, haaramine; "tunnetus annab seletuse [või avamise või kättesaadavaks tegemise või paljandi] (Aufschluss)" (samas: 21). Tehnika toob olemise esile teose kaudu - ta on teadmine ehk oskus olemist teosesse seada, teda teose kaudu seisu (zum Stehen) tuua (Heidegger 1999: 204; 1966: 122), ehk teose kaudu mõistetavaks, tunnetatavaks, kättesaadavaks teha. Inimene ja tõde ehk olemine piiravad teineteist. See tähendab, et inimene ja loodus ${ }^{13}$ kuulavad ja piiravad teineteist. Pidades silmas: a) Heideggeri arusaamist mõtlemisest kui teest, mis avab erinevaid vaateid enne "pärale jõudmist" ja ühtlasi kogub need vaated kokku (legein, lesen), ning b) tegevpõhjust (causa efficiens, arché $^{14}$ ), mis esimesed kolm "põhjust" (süüd või esiletoomist - aine-, kuju- ja eesmärk-põhjuse ${ }^{15}$ ) kokku koondab, vaimusilmas enda ette asetab, et siis need juba tegelikkuses nähtavaks muuta ühe valmis (tehnilise) eseme ehk teosena; näen ma siin järgmist seost. See tegevpõhjus, nt hõbesepp, on tehnilise mõtlemise teel, mis viib teda mägede vahele, kus avanevad erinevad vaated sellest, mille esiletoomist ta kavandab. See tee võib ka olla juba valmistamise tee, kus esialgselt vaimusilmas visandatud ese muutub nt sattumuslike asjaolude tõttu või seetõttu, et see tee (nt eseme materjal, kuju 
vm) ilmutab (entbirgt) end teisiti, kui esialgu arvatud: ese võib kord nii, kord teisiti välja kukkuda (Heidegger 1959a: 21). Eriti looduslik töödeldav materjal avab oma saladusi, toob oma iseärasused varjatusest välja hõbesepani, kui see mateeriaga töötab. Hõbesepp peab nende iseärasuste suhtes olema tähelepanelik, olukorraga kohanema, nt muutma toodetava eseme materjali või kuju.

Kaasaegne tehnika toob samuti välja (entbirgt), kuid mitte mäe tagant, vaid mäe seest - ta kaevandab välja ja toob maapinnale (herausfördern, zutage fördern). Ta ei otsi erinevaid vaateid, ei kohandu loodusega, maastikuga, vaid sunnib mäge end avama (erschliessen), ta tõstab looduse välja (herausstellen). Ta seega ei lase loodusel end juhtida, vaid juhib ise end läbi looduse ja kindlustab selle juhtimise toestikuga (Gestell) kaevandusšahtides ja muude vajalike struktuuridega (ainelise raamistuga), mis võimaldavad mäe sisu ohutult ja optimaalselt pinnale tuua ning seal edasi töödelda. Mägi (maapõu) muutub selle kaudu inimesele justkui (maapõuevarade) laoks, mis võetakse kasutusele (aufschliessen) ning mille oluline näitaja on nüüd tema varude seis (Bestand) kuna see peab raamistu seadmisel nähtud vaeva ära tasuma. Ühtlasi sulgeb see raamistu varasema tootmise, mis käis mõtlemise, koondamise teed, nii aherainemägede (Berg) kui kaevandusehitistega (verbauen).

Carolyn Merchant (1983a) kirjeldab mitmele allikale tuginedes (ta tsiteerib nii antiikautoreid Ovidiust, Senecat, kui ka renessansi- ja kaasaegseid autoreid: Paracelsus, McLuhan, Valentine) antiikaja arusaamist maast kui toitvast emast, kellest on sündinud kõik tema peal olev, nii elus kui eluta ja ka tema sees olev on tema ihuviljad. ${ }^{16}$ Maad kujutati inimesesarnase organismina, kellel on veresoonkond (jõed, mered) ning mitmed organismidele omased funktsioonid (hingamine, higistamine, ainevahetus). Maapõuevarade kaevandamist kujutleti kui Maaema üsa või sisikonna lahti lõikamist. Maa annab oma pinnale selle, mida ta tahab lubada inimesel kasutada, ning mida ta enda sees hoiab, seda ta ei taha lubada inimesel kasutada. Selline arusaam sisaldab endas ühtlasi moraalset hoiakut: maa kui ema, kui elu andja, toitja ja hoidja on püha, teda tuleb austada; tema sisemusest metallide ja kivimite väljakaevamine on tema pühaduse rüvetamine (mille eest ta ka kätte maksab, nt maavärinate näol), seega lubamatu, ebamoraalne.

Selline suhtumine püsis veel renessansiajal, kuid kaevandustööstuse kasvavad huvid kaubandusliku revolutsiooni tingimustes 16. sajandil sundisid looma uusi arusaamu maast ja loodusest. Nii kirjeldab Merchant nt Adamsile ja Agricolale tuginedes vana ja uue arusaama konflikti. Uued käsitlused püüdsid sisendada, et maa pole tegelikult hea toitev ema, vaid õel võõrasema, kes inimeste eest kasulikke varasid peidab, ning et kaevandamisest tekkivad kahjud (keskkonna reostumine ja hävimine) lubavad end tegelikult kasutoovalt rakendada (nt metallide sulatamiseks maha võetud metsade asemele saab 
rajada põlde ning kaevandamisest saadud tuludega saab korvata metsade näol kaotatud ehitusmaterjale). Vana suhtumise kaitseks rääkis aga inimeste endi moraalne laostumine kaevandamisega seoses: metallid tekitasid ahnust ja himu, ajendasid julmust ja vägivalda, saastades inimhinge nagu kaevandamine saastab maad. Samas nähti uut kaevandustegevust muutvat ka maad ennast: ta pole enam toitev ema, vaid sünnitab valimatult koletisi ning allub passiivselt nende vägivallale (Merchant 1983a: 111-112; Merchant viitab Spenserile 1595). Uute väärtuste (inimeste heaolu kasv maapõuevarade kasutuselevõtuga) tugevnedes kahanes ka vastalisus maa tehnilise uurimise-avastamise suhtes.

Kuigi Merchant möönab, et maavarade kaevandamise suhtes rakendati aegajalt ka varem nõrgemaid moraalseid sanktsioone, oli valdavaks siiski austav suhtumine maasse kui organismi. Sellest tulenevalt suhtuti ka kaevandamisse ning metallide töötlemisse suurema tähelepanuga: need olid seotud eriliste puhtuseriitustega, sepatööle ja -tööriistadele omistati eriline vägi. Näiteks ${ }^{17}$ keldid austasid neid paiku Maal, kust nad kaevandasid kivimeid või maake, sidusid neid Maa vaimude või hingedega, kellele nad selle eest ohverdasid. ${ }^{18}$ Seda võiks võrrelda Heideggeri mõtlemise ehk mõtiskluse teega: tähelepanu, mis koondati maapõue avamisele inimese hüvanguks ja selle rikkuste kasutamisele esemete loomiseks, on kui mõtluse tee, kus meel peab olema puhas ja märkama seda (mäe sisse) peidetut, tema, ning temast esemete, esiletoomist. ${ }^{19}$ Seevastu kaubanduslik pööre lõi meelestuse, mille kohaselt maapõu pidi kasu tooma rikkuse, au, tehnilise või sõjalise edu näol. Toimus kontseptuaalne muutus: maa ja temast sündinu polnud enam elusorganism, vaid nendega tuli arvestada tulude ja kulude võtmes - neid tuli mõõta ja arvutada; st, maa ja maapõu oli muutunud varuks (Bestand), millest tuleb kasu saada ja mille seisu (Bestand) tuli jälgida. ${ }^{20}$ Sellele vastavalt oli õigustatud mäendustegevus, maastiku ja looduse seadmine ehk tema ümberehitamine (ehk isegi rikkumine saastuse tekitamisega ja looduslike maastike struktuuri lõhkumisega) nii, et sealt kasutoovad maapõuevarad kätte saaks. Sellega ühtlasi suletakse varasemad koondava mõtiskluse teed, kuna neid pole võimalik kaubanduslikult hinnata.

Tehnika kui suhe Maaga ja kui maailma tunnetamine on sellega tõepoolest muutunud, mis puutub sellesse, mida ja kuidas ta esile toob: varasem tehnika keskendus konkreetsele asjasusele ja asjade haakuvusele üldises looduse ja ühiskonna tervikus. Asjad koondasid endas sammud, mis viisid nendeni igaüks omal viisil - õigemini öeldes, nende sammude astuja koondas need asjadeks; ehk avastades, kuidas olev (loodus, maa) on see, mis end esile toob, meelestab avastavat meelt ja sellega kujundab ehk piirab teda, mis omakorda kujundab viisi, kuidas avastaja meel kujundab avastamise teed ja seega maailma - mida ja kuidas esile tuuakse. 
Mis mäed esialgu mäeahelikuks lahti laotab [entfaltet] ning neid nende laotatud koosolus läbistab [durchzieht], see on koondav, mida me nimetame mäestikuks ehk mäestuks. Me nimetame toda esialgset koondavat, milles need viisid lahti laotuvad, mille järele meie meel on nii või naa, meelestuks /das Gemüt/ (Heidegger 1989: 1207).

[Was die Berge ursprünglich zu Bergzügen entfaltet und sie in ihrem gefalteten Beisammen durchzieht, ist das Versammelnde, das wir Gebirg nennen.

Wir nennen jenes ursprünglich Versammelnde, daraus sich die Weisen entfalten, nach denen uns so und so zumute ist, das Gemüt] (Heidegger 1959a: 27).

Mõeldes sellest tsitaadist mõtisklus-praktika kontekstis, tuletan temast järgmised ideed: mäestikku risti ja põiki läbi rännates (durchziehen), avanevad rändajale (mõtlejale, käsitöölisele, sepale) vaated; mäestik avaneb, esitab end üksikasjaliselt (entfaltet) ning häälestab rändaja meelestust. Kuigi rändajal on eelnevalt määratud eesmärk, laseb ta end mägedel juhtida, kusjuures iga mäe taga avaneb uus maailm ja juhib rändaja teekonda. See tähendab, et mõtleja, käsitööline, sepp mõtiskleb hoole ja tähelepanelikkusega selle materjali üle, millega ta töötab - selle maast tuleva tumeda, läbipaistmatu, varjava materjali (aine) üle, ${ }^{21}$ mida tuleb alles tunnetada; tähelepanelikult kombata tema olemise järele, et seda loodava eseme jaoks ja kaudu varjust välja tuua. See mäestu ehk varjustu (Gebirg) hoiab endas maad ja taevast, jumalikku ja surelikku, nende teineteise piiramist, mida inimene avab.

Mäendus ei lase end mägedel juhtida, leidmaks tõde, mis peidab end mäe taga. Vastupidi, ta juhib end läbi mäe, kindlustades oma tee toestiku ja raamistuga või avamisega otsese paljastamise kaudu, mille juures maa avab end pärani ja saab käsiteldavaks ressursside varuna mõõdetavates soontes ja kihtides. Nii ei ole tunnetuse suhe enam inimese kui arché ja asja olemisse tulemise vahel inimese ja looduse vastastikuses kuulamises, vaid pigem nagu laohoidja või kaupleja ja varu seisu vahel: maad ei nähta moraalse olendina, vaid tehnoloogilises raamistus või seadestus kui pelka ressursside kogumit tehniliseks rakendamiseks. Uusaja tehnika abstraheerub asjadest ja üldistab esemed abstraktseteks seosteks varuosade vahel, mis on oma kontekstist ja keskkonnast lahti kistud ning millel puudub oma eesmärk (telos); mateeria on temale vaid pelk materjal, eeldatavasti isomorfne, tagamaks eelnevalt määratud ühetaolise kujundamise lõpptulemuse tõsikindlust. James Weineri (2001: 92-93) sõnul kaob uusaegses tehnikas seega maa ja ilma vaheline pinge, mis ilmnes varasemates tehnoloogiates vastavalt nende iseärastele ajaloolis-kultuurilistele tajumisviisidele - kus maa ja ilm piiravad teineteist ja saavad 
tajutavaks teineteise taustal. Sellest on alles jäänud vaid 'erinevad staadiumid inimese valitsemises maa üle ning seda valitsemist takistavas vastupanus'.

\section{Uusaegne teadus ja tehnika kui looduse uurimise viisid: ökofeministlik lähenemine}

Eelmises osas kirjeldatud üldised ühiskondlikust praktikast võrsuvad eeldused looduse ja maa tunnetamise ning tehnika rakendamise seostest juhatavad teed tehnika ja teadusteooria seoste uurimisse. Üks eeldusi kaasaegse teaduse ja tehnika tekkeks on eelmises punktis käsitletud muutus suhtumises maasse ja loodusesse: maad ja loodust nähakse millenagi, mida saab jaotada alg- või varuosadeks ja tellimusena kätte toimetada (bestellen). Vaatlen lähemalt tehnika ja teaduse rolli looduse esile toomisel tema raamistu-päraselt osadeks jaotatuna. Siingi laenan ideid Carolyn Merchantilt teaduse ja tehnika praktikas ilmneva inimese ja looduse vahekorra konkretiseerimiseks. Kui eelmises osas oli juhtiv idee maa ja loodus kui ema, kelle laps inimene on, siis siin esineb loodus naisena ning inimest kujutatakse mehena, kes teda võrgutada püüab.

Heidegger eristab viisid, kuidas see, mida mägi pilgu eest varjab, varjamatusse tuuakse ehk kuidas temast tunnetus luuakse (Heidegger 1969: 77). Varasemat tehnikat näeb ta tegevusena, mis aitab loodusel endal välja ilmuda sellisena, nagu ta muidu ei ilmuks, koondades tema võimed eesmärgistatud asjaks. Uusaegset tehnikat näeb ta loodusele väljakutse esitamisena, tema ilmumise korraldamisena (Bestellung) teatud seadestu kaudu kindlate funktsioonide täitmiseks. Kui mäenduses korraldatakse maa selliselt, et maapõuevarad varuna pinnale ja kätte toimetatakse, siis tehnikas korraldatakse loodus selliselt, et ta esineb jõudude varuna. Sellist korraldamist on loodus Heideggeri järgi ise inimeselt nõudnud sellega, et inimene on tema jaoks pidevalt varjamatuses:

Niisiis kui inimene uurides, vaadeldes seab [nachstellt] ennast looduse kui oma ettekujutuse ühe ala järele, siis on ta juba kõnetatud ilmsikstoomise ühe viisi poolt, mis teda välja nõuab lähenema [anzugehen] loodusele uurimise ühe /vastas- ehk eesseisu ehk / esemena - niikaua kui ta / vastas- ehk eesseis ehk/ ese kaob koosseisu /vastas- ehk eesseisutusse ehk/ esemetusse (Heidegger 1989: 1207).

[Wenn also der Mensch forschend, betrachtend der Natur als einem Bezirk seines Vorstellens nachstellt, dann ist er bereits von einer Weise der Entbergung beansprucht, die ihn herausfordert, die Natur als einen Gegenstand der Forschung anzugehen, bis auch der Gegenstand in das Gegenstandlose des Bestandes verschwindet] (Heidegger 1959a: 26). 
Kuigi Ülo Matjuse tõlkes seab inimene ennast looduse järele, siis Heideggeri sõnakasutuse grammatika viitab pigem looduse jälitamisele (jemandem - der Natur als einem Bezirk seines Vorstellens - nachstellen). Seega: inimene jälitab loodust kui oma uurimisvaldkonda. See aga meelestab mind lugema järgmist tegevust looduse suhtes - angehen - kui ründamist või ründavat lähenemist: loodusele liginetakse kui vastasele. Temast saab reguleerimise objekt ja reguleerimine on rünnak tema autonoomsusele (ka Glazebrook 1998, 2000). Kaasaegne tehniline reguleerimine on mõõtev, kalkuleeriv ja arvet pidav - loodus taandatakse tema mõõdetavatele omadustele, millest tulenevalt kaob ta esemena ja saab pelgaks koosseisuks. Sellega tähendab tehnika looduse valitsemist, tema rakendisse, raamistikku asetamist; loodus kui vastane taandatakse kontrollitavate jõudude koosseisuks.

Samasugust ründavat ja jälitavat, väljakutsuvat seadestut rakendatakse teaduses (Heidegger 1959a: 29): füüsika seab loodust eksperimendis uurimaks, kas ja kuidas ta sel viisil seatuna endast märku annab. Eksperimendis koondab füüsika jõud teatud koosseisu (Bestand), ta korraldab (nachstellen) nad vajalikul viisil. Jõud peavad olema arvutatavad. Nagu kaasaegses tehnikas pole oluline konkreetne esemelisus, veelgi vähem asjasus - asi oma ("põhjuslike") seostega oleva tervikus - mis on isegi tühistatud; nii pole füüsikas olulised konkreetsed põhjuslikud seosed ega materiaalne ainulaadsus; pigem põhjuslikkus haihtub samaaegselt või üksteise järel paikaasetuvate varude väljakutsutud ilmumiseks (samas: 30). Siin, kaasaegses teaduses nagu ka tehnikas, ei sallita enam, et miski võib välja kukkuda kord nii, kord naa, oluline on tõsikindlus, ettearvatavus ja kontrollitavus, mida pakub oleva käsitamine koosseisuna, püsivusse ja seisu tooduna. Sellega (tehnoloogiline) teadus, eriti eksperiment kui tegevus, mis toob looduse teadusliku seadestu (matemaatilisse) kujju, teeb loodusele ülekohut, tehes oleva vaadeldavaks sellena, mis ta on (Glazebrook 1998).

Kuigi nagu Trish Glazebrook (2000) ütleb: kaasaegne teadus jätab looduse ilma tema telos'est, tema oma eesmärgist, sundimaks talle peale inimese määratud eesmärke, mis saavutatakse tehnoloogia abil, loodusega tehnilise ümberkäimise kaudu ${ }^{22}$ - nagu kaevandamises, nii ka tehnikas ja teaduslikus eksperimendis ei sõltu kogu toimuv (toimuv tõde, varjamatusse toodav) üksnes inimesest, ei ole tema võimuses:

Tehnikat käideldes võtab inimene seadmisest kui ühest ilmsikstoomise viisist osa. Kuid varjamatus ise, mille piires seadmine lahti hargneb, ei ole kunagi inimlik vägi [Gemächte] - sama vähe kui see vald, millest inimene igal ajal juba läbi käib, kui ta subjektina objekti taotab [bezieht] (Heidegger 1989: 1206). 
[Indem der Mensch die Technik betreibt, nimmt er am Bestellen als einer Weise des Entbergens teil. Allein die Unverborgenheit selbst, innerhalb deren sich das Bestellen entfaltet, ist niemals ein menschliches Gemächte, so wenig wie der Bereich, den der Mensch jederzeit schon durchgeht, wenn er als Subjekt sich auf ein Objekt bezieht] (Heidegger 1959a: 26).

Siin võib näha vihjet arusaamale, et inimene on kõigi asjade mõõt: inimene arvab end käivat looduse kohta ("kui ta subjektina objekti taotab", "wenn er als Subjekt sich auf ein Objekt bezieht"); s.t inimene mõõdab kõike enda järgi (oma raamistus) ning tal tekib kujutlus, nagu olekski loodus sellise kujuga, nagu selles raamistus paistab. Kuid Heidegger viitab, et just see arusaam, mis tuleneb pettekujutlusest, et loodus on täielikult raamistu kujuga (abstraktsete jõudude mitteesemeline koosseis), on inimese enda olemuse suurim ohustaja.

Siin lubab Heideggeri väljendusviis näha taas seoseid Merchanti käsitlusega, kaasaegse teaduse algusaegade arusaamaga loodusest ja teadusest. Kui inimesel oli juba moraalselt lubatav maa-ema, looduse sisse tungimine temas peituvate metallide ja kivimite kättesaamiseks, siis oli sellega kehtestatud inimese võim ja valitsemine looduse üle. Merchant (1983a) viitab peamiselt Francis Baconile kui uue moraalse hoiaku poolehoidjale ja laiendajale tehniliselt tegevuselt teaduslikule: inimene oli looduse valitseja, kuni ta naise süü läbi pärispattu langes ning Eedeni aiast välja heideti ja ta sellega oma võimu kaotas. Teaduse ülesanne on see võim taastada, ning see on võimalik vaid tungides looduse üska nagu kaevandusse ning vormides loodust nagu alasil. Loodust kujutatakse naisena ning inimese ülemvõimu taastamist looduse üle kui naise (vägivaldset) võrgutamist, tema tumedatesse soppidesse ja nurkadesse tungimist, et tema saladusi paljastada. Uusaegne teadus pidi aitama loodust tundma õppida, et siis seda teadmist kasutades teda inimese teenistusse rakendada, teda "vallutada ja allutada", koguni vägistada ja piinata kui nõiaprotsessil. Teaduslikus eksperimendis peab inimese teadmine aitama mehaaniliste kunstide abiga rakendada tema võimu looduse üle, lõigata loodus lahti ning vormida seda mehe käe läbi.

Merchant nimetab seda lähenemist seksuaalseks kujutelmaks. Tema tõlgendusega võib mitte nõustuda, nagu Alan Soble (2004), kes väidab, et Baconi allegooriat on vääriti tõlgendatud; ometi oli soo- ja seksuaalsuse allegooriatel ilmselt oluline mõju tolle aja ühiskonnale feminiinsuse alavääristamises ja maskuliinsuse ülendamises teaduse ja tehnika uurimise taustpõhimõteteks (Scharff \& Dusek 2004: 414), isegi kui see mõju ise tulenes Baconi vääriti tõlgendamisest. Selles valguses paistab Heideggeri käsitus looduse jälitamisest ja korraldamisest (nachstellen) ning tema ründamisest (angehen) sobivat hästi maskuliinse arusaamaga teadusest, kes loodust kui naisolevust jahib ja val- 
lutada püüab. Nii looduse ja maaga praktiline ümberkäimine (kaevandamine, tootmine) kui ka teoreetiline uurimine on tema sundimine teatud raamistiku (mehaanilised kunstid) kaudu end avama, oma saladusi ilmutama. See ilmutatu esineb teaduste jaoks abstraheeritud kujul kui varu (Bestand, osadeks lahti lõigatud koosseis, vt märkus 11), mida on võimalik allutada inimese tahtele ehk arvutada, modelleerida ning kasutada uute saladuste ilmsiks toomiseks looduse edasise vormimise kaudu. Günter Seubold (1986: 54) ütleb sama ning väljendab seda veel looduse ja asjade vägistamisena: neil ei lasta olla nemad ise, vaid nad sunnitakse sellesse kujju, millises nad (või neis peituvad jõud) inimesele kättesaadavaks osutuvad (samas: 110-111).

Mõlemas käsituses on ka olulised kaks omavahel seotud aspekti: esiteks on inimene looduse poolt sunnitud ehk välja kutsutud teda ennast väljakutsuvalt, sundivalt uurima. ${ }^{23}$ Merchanti esitusest saab selle välja lugeda Eedeni aia loo kaudu: naine-loodus meelitas mehe-inimese seisundisse, kus ta ei valitse enam loodust vaid on pigem tema poolt valitsetud, Heideggeri sõnadega - inimene on looduse jaoks varjamatuses, päästest väljas. Teiseks on uurimise käigus ilmnev vaid osaliselt inimese enda teha. See ilmneb nõudest, et looduse valitsemiseks tuleb loodust (tema saladusi) tunda, sest vaid loodust tundes, tema enda seadusi rakendades saab tema üle valitseda. Ma lisaksin siia veel ühe tõlgenduse Heideggeri mõistetest, tuginedes Hermann Otto Theodor Paulile (1992): inimene peab loodust nõrgestama ning tema välja toomine - Ent-bergen - teenib seda eesmärki, nõrgestab teda, tuues ta kindlast kohast välja varjamatusse - Unverborgenheit. Isegi kui inimene tehniliselt loodust juhib - ja Baconi arusaamas justnimelt siis - ilmutab loodus end - just iseend, mitte aga midagi inimese loodut, mitte inimese väge või tema tehtut (Gemächte).

Sellises feministlikus kontekstis tuleks juba küsida ka viimati nimetatud sõna - Gemächte - kohta: kas pole Heidegger just meelega sellist väljendit kasutanud? Eestikeelses tõlkes on selle koha peal 'vägi', mis võiks saksa keeli olla ka Macht vms, ning ingliskeelses tõlkes handiwork ehk Handwerk või ka Geschöpf (käsitöö, looming). Macht sobiks ka hästi, arvestades, et enne seadestut pidas Heidegger tehnika olemuseks mahhinatsiooni, toimetamist, seadmist Machenschaft (Lagdameo 2014). See kõlab ka hästi kokku eksperimentaalse meelestusega või teaduse ja tehnika faasiga, kus inimene on aktiivne, seades mateeriat, nägemaks, milliseid efekte ja kuidas ta esile saab kutsuda; sellele vastanduksid küps teadus ja väljaarenenud tehniline infrastruktuur, kus see efektide esile kutsumine ja selle eesmärgid on teaduse ja tehnika toimimises, nende kogu seadestus ja raamistikus sees kultuuri osana, mida inimene ise enam valida ei saa vaid toimib selle käitajana. Kas põhjus, miks Heidegger siin Gemächtet sobilikumaks peab kui Machti, on selles süsteemis eeldatava 
kalkuleeritavuse ja hallatavuse läbivuses ja totaliseerivuses (Dallmayr 2001: 255)? Ometigi see olekski süsteemi enda, mitte inimese, omadus, ning inimlike võimete puhul ei peaks saama millestki nii haaravast ja totaalsest kõnelda, nagu seda väljendab eesliide $G e$ - antud sõna puhul. Et Heidegger on valinud inimvõimete väljendamiseks tahtlikult mõiste, mida tänapäeval seostatakse peamiselt (mehe) sugulise võimekusega, oletab ka Johannes Fritsche, kes analüüsib soomõistete Geschlecht ja Gemächte kasutamist Heideggeri teostes (Fritsche 1999: 188-194). Merchanti arutlus lubab oletada, et rohkem või vähem teadlikult on soolise ülemvõimu ja võimekuse kujutlus tõepoolest kujundanud uusaegse teaduse ja tehnika olemust. Ehk on Heidegger tehnika olemust või selle taotletavat toimet ka sellisel viisil tajunud? See oleks kooskõlas tema hoiakuga kaasaegse tehnika suhtes, kuna ta väljendab eksplitsiitselt ja teravalt seda, mis peitub implitsiitselt teaduslik-tehnilises maailmavaates - meheliku domineerimist ja naiseliku allasurumist - seejuures heites kõrvale selle vaate õigustatuse.

\section{Kokkuvõte. Kaasaegse tehnoloogia maailm}

Üleminek metafoorilt maast kui toitvast emast metafoorile maast kui inimese ihadele, ahnusele ja suvale alluvast hoorast harmoneerub Glazebrooki (2000) käsitlusega sellest, kuidas Heidegger käsitab muutust looduse mõistmises kaasaegse teaduse ja tehnoloogia metafüüsika raamis. Aristotelese mõistes oli nii tehistele kui ka looduslikele asjadele omistatud kõik neli põhjust ehk osaks saatmist: arché - toimija ehk põhjus, yle - mateeria (materjal, aine), morfé ehk eidos - kuju, ja telos - eesmärk. Seega loodust nähti iseendas, inimesest sõltumatult eesmärgistatuna. Kuid teadus tühistas looduse enda eesmärgi, looduse teleoloogiline mõiste asendati teoreetilisega, mis oli defineeritud matemaatiliste homogeensete dimensioonidega nagu ruum ja aeg, milles loodusest saab mõõtmise, eksperimendi ja arvutuse kaudu arvude hulk (Heidegger 1959a, b; Glazebrook 1998; Heisenberg 1958). See on looduse suhtes ülekohus ja vägivald (Glazebrook 1998), sest inimene ei kuula teda enam, vaid defineerib ja seab teda ette vastavalt oma suvale ja pretendeerides tõele tema kohta, eeldefineeritud matemaatilis-arvulisele tõele. Selle asemel, et tähelepanuga kuulata loodust ja temaga hooles ümber käia, hoiab inimene teda nüüd oma läbiuurimise ja vaatluse all. Loodusest on saanud avalik naine, kellelt on võetud õigus oma olemisele, privaatsusele ja tahtmisele, kelle saladused peilitakse välja kogu inimkonnale vahtimiseks ja oma huvides ärakasutamiseks. Tehnoloogiline vaade maailmale - ja maale - mis taandab nad ressurssideks, ${ }^{24}$ mida tuleb arvutada kulude 
ja tulude mõistetes, hankida hulgiinventarina ning allutada inimese tahtele ja toimimisele, on järjekordne rünnak tema vastu. See sarnaneb suhtumisega inimolendeissegi, kellest sageli mõeldakse kitsalt kui mingite funktsioonide täitjatest või pigem isegi kuuluvana nende funktsioonide täitjaskonda ja ainult sellena relevantsetest (väljendid nagu 'liiklejad', 'kahuriliha' jmt). ${ }^{25}$ See taandamine vastab tehnoteaduse Gestell-ontoloogiale ja Bestand-ontikale.

Varjamatus kui maa, mäe avamine, muudab maailma. Inimene tahab päästet ja maa maksab selle eest enda päästega. Inimene usub enda turvalisusse, kui ta on teinud maa ilmaks ja ilma süsteemiks, mida ta saab hallata ja ümber korraldada. See uskumus lahkneb sellest, mida Heidegger peab ontiliselt kehtivaks - et inimese võimuses ei ole see, kuidas loodus end varjamatusse toob. Ta rõhutab episteemilist ebakindlust ontilise läbipaistmatuse ja maa tumeduse tõttu veelgi enam oma essees (1980), vastandades maad materjalile kui tehnilisele mõistele. Tõde jääb varjatuks. See lahkneb ka inimese enda olemisest: kus ta kujutleb end looduse üle valitsevat tänu oma tehnoteaduslikule seadestule, mida ta usub avavat tõe looduse kohta, on ta tegelikult ise selles seadestus ja raamistus kinni, saades selle kujuliseks: ta näeb iseend arvutatava, saadaval oleva ressursina. Nagu teadus on vabastanud lummusest looduse, on ta vabastanud lummusest ka inimese, olles väidetavalt kaevandanud välja nende metsikuse ja näidanud nende mõistestatavust ja arvutatavust, on ta seega arvutamisega eemaldanud kõik nendega seotud hoole ja tabud.

Toodud analüüsi ja mõtisklusi võiks veel edasi arendada erinevates suundades, eriti võrrelda Heideggeri arusaamadega analüüsitud mõistetest nagu 'maailm' või 'varjamatus' tema teistes teostes, kehalisuse ja soolisuse mõistetest, samuti veel rohkem süvitsi kriitiliselt võrrelda ajaloolist ja kaasaegset tehnoloogiat ja maailmapilte ning soostereotüüpe, mis kindlasti on sügavalt sees ka Merchanti jutustuses ning osaliselt selle kaudu siinses analüüsis. Need analüüsid vääriksid omaette edasi arendamist ega mahuks käesolevasse artiklisse. Siin loodan olevat avanud ühe võimaliku vaate varjamatuse mõistele, mida Heidegger ise võib-olla üldse päris nii ei mõelnud, kuid Merchanti ökofeministliku jutustuse prisma kaudu vaadates mulle niimoodi paistab.

\section{Tänusõnad}

Selle töö valmimist on toetanud ETF grandid IUT 20-5 ja 7946, Haridus- ja Teadusministeeriumi grant SF0180110s08, Euroopa Liidu Regionaalarengu Fond (Eesti-uuringute Tippkeskus TK 145) ning Tartu Ülikooli grandid PFLFI15915 ja PHVFI16941. 
Tänan Ülo Matjust, Janar Mihkelsaart, Daniel Gruschket, Andreas Demantit, Rein Vihalemma, Frank Suttnerit ja Magdalena Ziętekit, kelle ideed on otsesemalt või kaudsemalt aidanud kaasa selle artikli valmimisele, ning kaht anonüümset retsensenti, kelle põhjalikud märkused aitasid lõppversiooni parandada. Tänan ka Piret Kuuske, Rafaela Hillerbrandi, Endla Lõhkivit, Joseph Rouse’i, Ena Metsa, Tõnis Metsa, Reet Metsa, Winfried Lotz-Rambaldit, Ruth Jürjot ja Riho Reiljani, kelle toetus või kellega mõttevahetused aitasid mind artikli valmimise jooksul.

\section{Kommentaarid}

1 See artikkel on edasiarendus prof Ülo Matjuse juhendamisel aines "Allikteos filosoofia ajaloo õppetooli poolt" alanud tööle, mis kohandatud kujul sisaldus mu doktoritöös (Mets 2013) ning veelgi parandatud kujul ilmus 2018. aastal ajakirjas Eidos. Revista de Filosofía de la Universidad del Norte nr 29 pealkirjaga "Female mountain, masculine mining: an interpretation of Entbergen", lk 119-149.

2 Tänu prof Ülo Matjusele paljude kannatlike selgituste eest Heideggeri filosoofiast. Meie vahel säilivad siiski olulised lahkarvamused, kuna ma jään suures osas oma (vääriti)mõistmiste ja (väär)tõlgenduste juurde, mille ta maha laitis - kuna mu fookuses pole Heideggeri filosoofia, vaid mu enda arusaamine kaasaegsest maailmavaatest ja selle normatiivsusest ning sellest, kuidas Heideggeri lugemine on mul aidanud neid teatud tasandil mõista ja mõistestada.

3 Kuigi mu siin esitatud käsitus on Heideggeri nimetatud artiklist inspireeritud, ei pretendeeri ma selle ühilduvusele kogu Heideggeri filosoofiaga.

${ }^{4}$ Heideggeri enda näide maaharimisest (nt 1959a) on muidugi samavõrra maaga seotud.

5 Sõna-sõnalt 'mäest/päästest väljasolu'.

${ }^{6}$ Ka balti keeltes viitab sõna 'maailm' - 'pasaulis' (lt), 'pasaule' (lv), sõna-sõnalt 'päikesealune' - millelegi valgustatule, tunnetusele avatule, slaavi 'mir' inimestele, rahule, kooskõlale, korrale, valgusele (Vasmer \& Trubachev 1964-1973: 626), ladina 'mundus' korrale, selgusele, puhtusele, päikesevalgusele (www.etimo.it); eesti 'maailm' tumeda ja läbipaistmatu maa ning heleda ja läbipaistva ilma (taeva, atmosfääri) koosolule (http://heli.er.ee/helid/970321.mp3 - 12.03.2019; Metsmägi jt 2012: 91).

7 Mis tähendus on seisul / paigal püsimisel tunnetuse seisukohalt? Kujutlege taktikalist olukorda: mida kauem üks vaenutsevatest pooltest paigal püsib, seda suurema tõenäosusega on vastasel võimalik ta asukoht teada saada ja sellele vastavalt rünnakut kavandada ja teha seda edukalt. Kui aga see üks pool pidevalt liigub, pole vastasel kindlat ja püsivat teadmist tema asukohast, mille alusel talle vastu astuda.

8 See tõe mõiste pärineb tõenäoselt Antiik-Kreeka olemise põhja (põhjuse) (arché) mõistest kui seisnev armastuse ja riiu vastastikuses vastasseisus ja tasakaalustamises (Kelsen 1939/1940: 90). Ka Heidegger 1980.

9 Fysis oli kreeklaste jaoks see, mille liikumapanev jõuad on temas endas - nt looduslikud asjad nagu taimed ja loomad.

${ }^{10}$ Lisaks eelnevalt antud tähendustele: riiul, raam, tugisõrestik. 
${ }^{11}$ Bestand - inventar; populatsioon; varu; kapital, ladu; püsivus; jätkuvus; saak; varuosad.

${ }^{12}$ Glazebrooki tõlgendus Gestell'ist viitab samuti sellele aspektile: "asjade ilmsiks toomise viis, mis seab nad inimese käsutuseks kättesaadavate ressursside püsivaruna" (Glazebrook 2000: 113; minu kursiiv).

${ }^{13}$ púors - mis on omaenda muutumise aluseks (Glazebrook 2000: 99)

14 Tehiste puhul on tegevpõhjuseks neid loov inimene; looduslike asjade puhul, nt taimed ja loomad, see looduslik asi ise (fysis) - nende liikumapanev jõud on neis endis.

${ }^{15}$ Causa materialis, causa formalis, causa finalis ehk yle, morfé ehk eidos, telos; ning causa efficiens - arché - toimija ehk põhjus.

${ }^{16}$ Maa-ema kujutlus ulatub antiigi-eelsesse aega - näiteks esines see ka sumeritel (Campbell 1962: 108) ning üldisemaltki (Eliade 1978: 53-55; Campbell 1960: 6667). Siiski tuleks arheoloogiliste leidude matriarhaadi- või feministlikus võtmes tõlgendamisega olla ettevaatlik, sest sageli puuduvad selleks piisavad tõendid (Hutton 1998: 36-41).

${ }^{17}$ Näide pärineb Frank Suttnerilt ekskursioonilt Aacheni pühadesse paikadesse kevadel 2012.

${ }^{18}$ See näitlikustab Heideggeri (1959c) asja (aseme; Ding) mõistet kui nelisuse (Geviert) maa ja taeva, surelike ja jumalike, koondamispaika: maa või paigad, eriti kaevanduspaigad, olid keltide jaoks sellised asemed, mis hõlmasid jumalikku, mitte pelgad ressursside varud. Veelgi enam, tänulikkus nende paikade suhtes annab tunnistust maa personifitseerimisest - tal võib olla oma telos, kuid ta sellegipoolest on nii lahke ja jagab inimesega oma üsa vilju.

${ }^{19}$ Asjadega käidi ringi tähelepanu ja hoolega; Glazebrook (2000: 109) arvab "varustuslikkuse ja asjade haaratuse konteksti" kuuluvat asjade konstitutsiooni hoolsas ringikäimises, vastandades seda teoreetilisele hoiakule, kus "selline haaratus ei kuulu olenditele."

${ }^{20}$ Glazebrook (2000: 113) väljendab sarnast arusaamist tehnilise Gestell'i tähendusest: loodust surutakse nurka "avamaks ja paljastamaks tema energiat varude kuhjamiseks”. Ka Dallmayr (2001: 261-262) rõhutab süsteemi efektiivsuse olulisust kapitalismi tingimustes, kus muud kaalutlused, nagu hool või süsteemi mõju (inim)olenditele, on välised asjaolud, müra.

${ }^{21}$ Vt ka Heidegger 1980.

${ }^{22}$ John Lunstroth (2009) ütleb: 11.-19. sajandil väideti loodusel puuduvat oma moraal ja olemus.

${ }^{23}$ Nagu Ülo Matjus selgitas, pole Gestell inimese teha, miski, mida ta välja mõtleb ja loodusele peale asetab; pigem on inimene looduse poolt Gestell'i välja nõutud, ta leiab end väljapääsmatult sellesse sunnituna ega saa sellest välja. Gestell on normatiivne ses mõttes, et inimene peab sellele vastavalt toimima. Kui seda tuleb mõista selles mõttes, et inimene on sunnitud teatud tehnilis-ühiskondlikku olustikku, millesse ta on sündinud ja kasvanud igapäeva elus, nagu ma Ülo Matjust mõistsin, ei erine see kuigivõrd varasematest (antiiksetest) inimolustikest, kuna igal ajastul sünniti teatud tehnilis-ühiskondlikesse oludesse, mis määras mõtlemisviisid ja tajud ja seadis kalduvusi, nii et selle olukorra väljapääsmatus ei saa kvalitatiivselt eristada kaasaegset tehnoloogiat varasemast. Pigem võib olla, et kaasaegses olukorras on 
tehnoloogia igal pool, maailm (loodus) on ise defineeritud tehnilistes mõistetes (väljendatud võimatusena mõista maailma ilma oskamata teda modelleerida, mõõta või manipuleerida; nt Bacon, Kepler jt; Hand 2004: 4-5; Feynman 1965: 58; Heidegger 1959b: 58, tsiteerides Max Plancki), kuna võimalused puutuda kokku loodusega ilma inimliku või tehnilise vahenduseta on üha napimad. Vt ka Heisenberg 1958.

${ }^{24}$ Vt ka Bunge 2003.

${ }^{25}$ Eriti teravalt ja siinse kontekstiga haakuvalt ilmneb selline suhtumine naise taandamises pelgaks seksuaalse rahulduse ressursiks, mida hankida allahindlusega. Sellist hoiakut väljendatakse eksplitsiitselt Tina Solimani ja Sonia Kennebecki dokumentaalfilmis "Sex: Made in Germany" (DokuKinoDE 2013, 23:56 ja 42:30), mis annab tunnistust sellise mõttelaadi levikust.

\section{Kirjandus}

Agassi, Joseph 1956. The Function of interpretations in physics (väitekiri). London: University of London.

Auberle, Anette (toim) 2001. Duden. Herkunftswörterbuch. Etymologie der deutschen Sprache. [die Geschichte der deutschen Wörter bis zur Gegenwart ; 20000 Wörter und Redewendungen in ca. 8000 Artikeln]. Mannheim u.a.: Dudenverlag.

Bunge, Mario 2003. Philosophical inputs and outputs of technology. Scharff, Robert C. \& Dusek, Val (toim). Philosophy of technology. The Technological Condition: An Anthology. Malden MA [etc.]: Blackwell Publishing, lk 172-181.

Campbell, Joseph 1960. The Masks of God: Primitive Mythology. London: Secker \& Warburg.

Campbell, Joseph 1962. The Masks of God: Oriental Mythology. London: Secker \& Warburg.

Dallmayr, Fred 2001. Heidegger on Macht and Machenschaft. Continental Philosophy Review 34, lk 247-267.

Eliade, Mircea 1978. A History of Religious Ideas. Volume 1: From the Stone Age to the Eleusinian Mysteries. The University of Chicago Press.

Fritsche, Johannes 1999. Historical destiny and national socialism in Heidegger's Being and Time. University of California Press (http://publishing.cdlib.org/ucpressebooks/vie $\mathrm{w}$ ?docId=ft5k4006n2; brand=eschol -20 . märts 2019).

Glazebrook, Trish 1998. Heidegger on the experiment. Philosophy Today. A Quarterly Survey of Trends and Research in Philosophy Directed to the Interests of Scholars and Teachers within the Christian Tradition 42 (3), lk 250-261 (doi: 10.5840/ philtoday199842326).

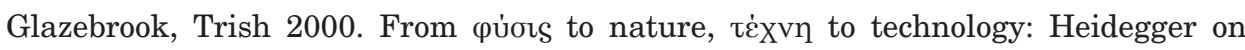
Aristotle, Galileo, and Newton. The Southern Journal of Philosophy 38 (1), lk 95-118. 
Grimm, Jacob Ludwig Carl \& Grimm, Wilhelm Carl 1854-1961. Deutsches Wörterbuch. Leipzig: Hirzel.

Hand, David John 2004. Measurement Theory and Practice. The World through Quantification. Oxford University Press

Heidegger, Martin 1959a. Die Frage nach der Technik. Vorträge und Aufsätze. Verlag Günther Neske Pfullingen, lk 13-44.

Heidegger, Martin 1959b. Wissenschaft und Besinnung. Vorträge und Aufsätze. Verlag Günther Neske Pfullingen, lk 45-70.

Heidegger, Martin 1959c. Das Ding. Vorträge und Aufsätze. Verlag Günther Neske Pfullingen, lk 163-185.

Heidegger, Martin 1965. Vom Wesen des Grundes. Wegmarken. Frankfurt am Main: Vittorio Klostermann, lk 21-72. [Esmatrükk 1929. Vom Wesen des Grundes. Jahrbuch für Philosophie und phänomenologische Forschung 10 (Suppl.), lk 71-110.]

Heidegger, Martin 1966. Einführung in die Metaphysik. Max Niemeyer Verlag Tübingen.

Heidegger, Martin 1980. Der Ursprung des Kunstwerkes. Holzwege (6. Auflage, 1-72). Frankfurt am Main: Vittorio Klostermann.

Heidegger, Martin 1989. Küsimus tehnika järele. Akadeemia 6 (tlk Ülo Matjus), lk 11951222 .

Heidegger, Martin 1999. Sissejuhatus metafüüsikasse (tlk Ülo Matjus). Tartu: Ilmamaa

Heisenberg, Werner 1958. The representation of nature in contemporary physics. Daedalus 87 (3), lk 95-108.

Henry, John 2001. Animism and empiricism: Copernican physics and the origins of William Gilbert's experimental method. Journal of the History of Ideas 62 (1), lk 99-119 (doi: 10.1353/jhi.2001.0004).

Hutton, Ronald 1998. The Pagan Religions of the Ancient British Isles. Their Nature and Legacy. Oxford ja Cambridge: Blackwell.

Kelsen, Hans 1939/1940. Die Entstehung des Kausalgesetzes aus dem Vergeltungsprinzip. Journal of Unified Science (Erkenntnis) 8 (1/3), lk 69-130.

Kluge, Friedrich 1989. Etymologisches Wörterbuch der deutschen Sprache. Berlin \& New York: Walter de Gruyter.

Lagdameo, Federico José T. 2014. From Machenschaft to Ge-stell: Heidegger's Critique of Modernity. Filocracia 1(1), lk 1-23 (http://www.filocracia.org/issue1/Lagdameo_Feb2014. pdf-21. märts 2019).

Lunstroth, John 2009. Aping Political Science. The American Journal of Bioethics 9 (5), lk 15-17 (doi: 10.1080/15265160902792498).

Matjus, Ülo 1989. Tehnika järele küsimise järel: Martin Heideggeri tõlkimisest. Akadeemia 6, lk 1222-1227. 
Merchant, Carolyn 1983a. Mining the Earth's womb. Rothschild, Joan (toim). Machina ex dea: Feminist perspectives on technology. Oxford: Pergamon Press, lk 99-117.

Merchant, Carolyn 1983b. The Death of Nature. Women, Ecology and the Scientific Revolution. San Francisco: Harper \& Row.

Merchant, Carolyn 2005. Science and Worldviews. Merchant, Carolyn. Radical Ecology. The Search for a Livable World. Second Edition. New York: Taylor \& Francis, lk 41-62.

Mets, Ave 2013. Normativity of scientific laws. Doktoriväitekiri. Tartu Ülikool (http:// dspace.ut.ee/bitstream/handle/10062/31611/mets_ave.pdf - 21. märts 2019).

Metsmägi, Iris \& Sedrik, Meeli, \& Soosaar, Sven-Erik 2012. Eesti etümoloogiasõnaraamat. Tallinn: Eesti Keele Sihtasutus.

Parhomenko, Eduard 2009. Martin Heidegger. Annus, Epp (toim). 20. sajandi mõttevoolud. Tallinn, Tartu: Tartu Ülikooli Kirjastus, lk 229-262.

Paul, Hermann Otto Theodor 1992. Deutsches Wörterbuch. Bedeutungsgeschichte und Aufbau unseres Wortschatzes. 10. Überarbeitete und erweiterte Auflage von Helmut Henne, Heidrun Kämper und Georg Objartel. Tübingen: Max Niemeyer Verlag.

Scharff, Robert C. \& Dusek, Val (toim) 2003. Philosophy of technology: The technological condition: An anthology. Malden MA [etc.]: Blackwell Publishing.

Seubold, Günter 1986. Heideggers Analyse der neuzeitlichen Technik. Freiburg \& München: Verlag Karl Alber.

Soble, Alan Gerald 2003. In defence of Bacon. Scharff, Robert C. \& Dusek, Val (toim). Philosophy of technology: The technological condition: An anthology. Malden MA [etc.]: Blackwell Publishing, lk 451-466.

Vasmer, Max Julius Friedrich \& Trubachev, Oleg Nikolaevitš 1964-1973. Etimologicheskii slovar' russkogo iazyka 1-4. Moskva: Progress (http://etymolog.ruslang.ru/ - 20. märts 2019).

Weiner, James F. 2001. Tree Leaf Talk. A Heideggerian Anthropology. Oxford \& New York: Berg.

Wrathall, Mark A. 2005. Unconcealment. Dreyfus, Hubert L. \& Wrathall, Mark A. (toim). A Companion to Heidegger. Blackwell Publishing, lk 337-357. 


\title{
Summary
}

\section{Female mountain, masculine mining: An etymological- feminist view on Entbergen in the essay "The Question Concerning Technology"}

\author{
Ave Mets \\ Research Fellow, Department of Philosophy \\ University of Tartu, Estonia \\ avemets@ut.ee
}

Keywords: history of science, history of technology, Martin Heidegger, scientific-technological metaphysics, worldview

Unconcealment is truth in Heidegger's Greek-inspired view - the kind of truth that underlies propositional truth (or correctness), as it concerns the entities that propositions are about, and how they come forth to us. This happens in Entbergen or bringing forth. Technology is one way of bringing forth. There are essential differences between the unconcealments of ancient and contemporary technologies. The first, according to Heidegger, went on the concernful way of contemplation, of mutual hearing of the creative being and the matter created of - man helped the being come forth in a way it by itself would not have done, by attending it concernfully. The latter is determined by enframing (Gestell) that is the essence of contemporary science and technology - a forcing of the world into a calculable and manipulable form.

I will give an etymological-ecological-feminist account of the essences of ancient and contemporary technologies as ontogeneses, and of their unconcealments and turning points on the basis of Carolyn Merchant's ecofeminist tale about mining practices. Those earth-related practices brought forth changes not merely in technologies, but also in mentality in times of commercial revolution and the birth of contemporary science. As she recounts, ancient mining practices were guided by the prevailing view of earth as a living organism, particularly as the mother of all that is growing in and on her, including the ores. Mining was conceived as digging into her womb and entrails to force her fruits out of her - and that was considered immoral and required special care and purity. Commercial revolution brought about a mind-set according to which this forcing of the earth is justified because she as a mean stepmother keeps her fruits so much needed by her children - the humankind.

I understand Merchant's tale to be about the practices and corresponding attitudes of those times. As language is a practice interwoven in other practices, I consider the etymologies of some related words to hint to the dominant ideas. Thence the words related to earth and world, whereas earth is the dark and concealing, and world is the known and transparent; or 'berg' as the saving both for what is inside it such as ores to be mined, and what is behind or on it. This iconically illustrates Heidegger's unconcealment as Entbergen exclusively used in this essay - 'bringing out of mountain or salvage'. Many other words used by Heidegger here are closely related to mining and commercial practices. Hence in technological practices, bringing the earth out of salvage became 
commonplace, and similarly bringing nature out of salvage, or disenchanting it, became the leading idea of the young science's agenda.

Technological view of the world is of resources to be measured and manipulated. Scientific view of the world is of forces to be calculated and reapplied to take control over nature. Merchant cites early scientists' ideas of subsuming nature to their power to reveal her secrets (the laws of nature) just like subsuming a woman to a man's power and shaping her according to his will. Boosting masculinity to the principles of science and deploring femininity parallel the moral decline in man's relation to earth and nature. Those became mere reserves - Bestand - in man's disposal, control and calculation, both scientifically and technologically, and thereby in quotidian thinking. 